\title{
Pictorialism in the AMERICAN West
}

\author{
RACHEL SAILOR $\uparrow$ UNIVERSITY OF WYOMING $\uparrow$ LARAMIE, WY
}

\begin{abstract}
$\uparrow$ ABSTRACT
Early twentieth century (1900-1945) photography of northwestern Wyoming (including the Teton and Yellowstone areas) fits into a paradigm of regional photographic production that either conforms to the documentary or pictorial aesthetics most common in the era. Pictorial photography, especially, links the region to larger trends in the nation and can be analyzed to uncover previously unexamined assumptions about the value of photographic aesthetics and regional production within the milieu of fine art photography in the United States prior to WWII.
\end{abstract}

\section{$\downarrow \quad$ INTRODUCTION}

Photographic pictorialism in the American West was an aesthetic movement, coterminous with the rise of regionalism, which reached its height in the late $1920 \mathrm{~s}$ and $30 \mathrm{~s}$. The photographic style as a product of the regionalist impulse goes largely unexplored for many reasons. First, pictorialism was an approach to photography that was overthrown (seemingly) by the modernist movement, in America first mounted in art photography by Alfred Stieglitz and his famous image, The Steerage, from 1907. Second, the hegemony of New York and the upper East Coast in the early twentieth-century American art world seemed close to absolute. In the third and fourth decade of the century, despite an interest in western lands by many artists - most notably Georgia O'Keeffe, Edward Weston, Ansel Adams and Group $\mathrm{f} / 64$ - the West was still considered a cultural backwater, its precise attraction for many modernists. Finally, that pictorialism in the West is not a common scholarly subject has to do with the nature of regionalism - the conceptual home for amateur and hobbyist pictorialists - that was splintered and decentralized by definition.

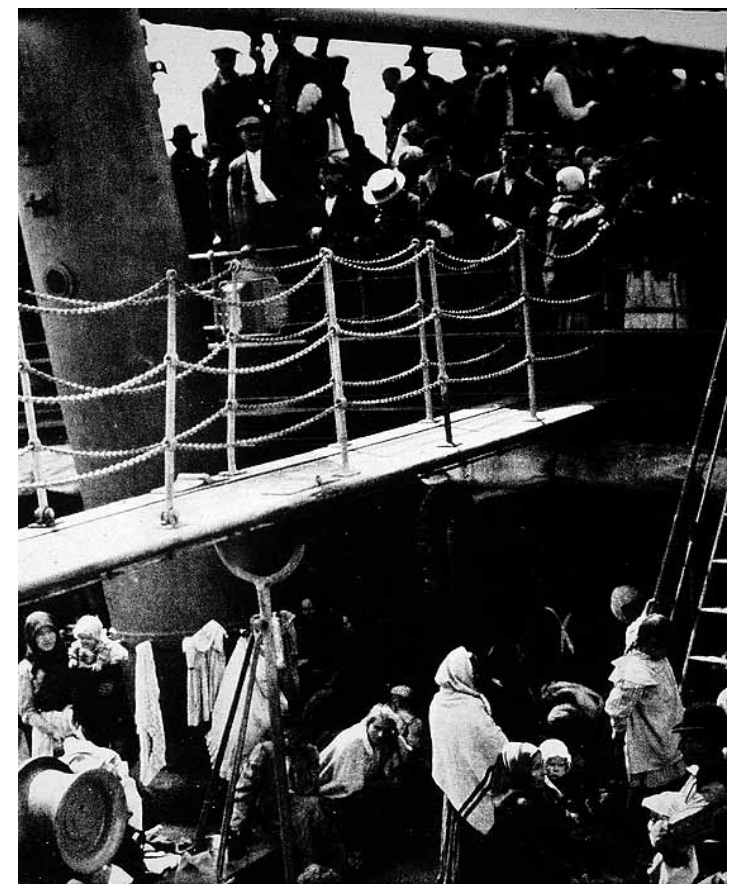

Stieglitz, The Steerage, 1907

Aesthetically, pictorialism was an approach to photography that emphasized romantic artfulness. Through the use of soft focus lenses, textured paper, and self-conscious compositional techniques borrowed from trends in painting and printmaking, the style was originally an effort to legitimize the mechanical medium of photography. Begun in the late nineteenth century in Europe by Henry Peach Robinson and encouraged through organizations like the Brotherhood of the Linked Ring, pictorialism was for a time associated with the avant-garde of the fine arts. While never really accepted in the nineteenth century as artists equal to painters, pictorialists aggressively co-opted their fine art technique and conceptual approach. For example, the craftsmanship 


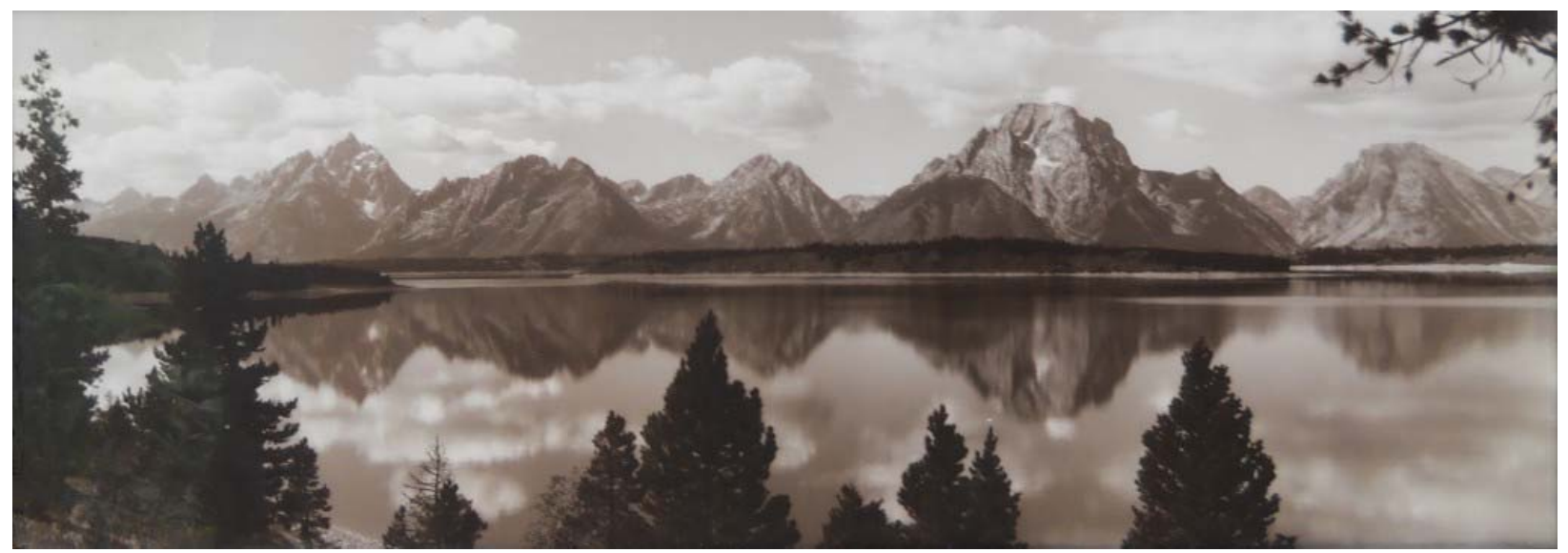

Harrison Crandall, Panorama View of Teton Range

of a pictorialist photograph was a response to the pervasive Arts and Crafts Movement that championed high quality workmanship and an insistence on aesthetic beauty. Moreover, the approach to photography drew heavily on symbolist sentiment in avant-garde art from the turn of the century; imagery in pictorial photography emphasized archetypes and favored universal motifs.

The regional aesthetic in the visual arts of the American West in the first decades of the twentieth century was considered thoroughly provincial in the cultural sphere of artistic visual production. That provinciality episodically provided much needed cultural isolation for the burgeoning modernists, but even the artistic centers such as Los Angeles and Toas/Santa Fe in the early twentieth century were anomalous and not fully acknowledged centers of anything. In the 1920 s and 1930 s, when regionalism and its kin emerged in response to WW I and the Great Depression and then was largely crushed by the postwar American art market, western centers of art that had expanded to include San Francisco and other major cities were still peripheral to the hegemony of the upper East Coast.

As early as 1900 photography critics took note of "a too definite desire...to overestimate and encourage the work of a very small circle" and "a very pronounced effort of the Eastern leaders to discourage any other salon, save the ones in which they personally figure." ${ }^{\prime 70}$ Western pictorialism, indeed western photography in general does not have to be considered a shadow of East Coast art, but as a regional stylistic incarnation that spawned and continues to spawn

70 Arthur Hewitt, "The Pictorial Movement: An Afterword," The Photographic Times, Nov. 1, 1900 32/2 pg.481. artistic approaches, interpretations and aesthetics that are profoundly meaningful for the history of the United States.

\section{$\uparrow \quad$ MeThODS}

My research relies heavily on primary sources, both textual and visual. These sources, I believe, are the best way to enter into past discussions and debates. In addition to artist archives and manuscript collections, photographic periodicals such as Camera Craft, The American Amateur Photographer and many others are a rich and underutilized resource. Secondary scholarship also usefully offers new approaches. Of particular importance to this project is Christian Petersen's After the PhotoSecession (1997), and scholarship in the increasingly dynamic field of Regional Studies, including Douglas Reichert Powell's Critical Regionalism (2007) and Robert Dorman's Hell of a Vision: Regionalism and the Modern American West (2012).

Conceptually the "interaction and intersection" model for understanding cultural forces is a more appropriate research methodology for this study as opposed to seeing changes in cultural production as a result of a binary/dichotomous tension. This approach was first introduced to me in Glenda Riley's "Writing, Teaching, and Recreating Western History Through Intersections and Viewpoints," (2000) and guides my research question that will consider alternatives to the more canonical model. 
The Teton Historical Society and Museum, and the photography collections of the Grand Teton National Park are repositories that hold collections that exemplify regional production across the American West. The photographs of unknown photographers in the region as well as the more well-known work of Teton photographer Harrison Crandall provides support for my investigation into regional photographic production as a phenomenon.

\section{$\uparrow \quad$ PRELIMINARY OUTCOMES}

My preliminary investigation in NW Wyoming is part of a larger project. Pictorialism in the American West will be the first wide-ranging book length study to address the broad concerns of pictorialism in the West from 1900-1945. The manuscript is divided into four sections that will cover the following topics: (1) Defining American Pictorialism, (2) Pictorialism in the American West, (3) Pictorialism and Native America, and (4) From Pictorialism to Modernism.

To date I have accomplished archival research at the Center for Creative Photography, Arizona State History Museum, Arizona State Historical Society, Arizona State University's Special Collections, the Getty Research Institute (with a grant from the University of Wyoming), University of Wyoming American Heritage Center, and Utah Museum of Fine Art. With the help of a Charles Redd Center for Western Studies grant, I have been able to visit the following repositories: University of Washington Special Collections, Buffalo Bill Center of the West, Center for Southwest Studies in Durango, Colorado, and the Palace of the Governors Photo Archive. I will also be a scholar in resident at the Georgia O'Keeffe Research Center from January to May, 2015.

\section{$\uparrow \quad$ LITERATURE CITED}

Corn, W. 1999. The Great American Thing: Modern Art and National Identity, 1915-1935. University of California Press, Berkeley, CA

Cornell, D. 1999. Camera work and the fluid discourse of pictorialism. History of Photography 23: 294-300.

Dorman, R. L. 2012. Hell of a Vision: Regionalism and the Modern American West. The University of Arizona Press, Tucson, AZ.

McCauley, E. A. 2012. The making of a modernist myth. Pages 16-65 In: The Steerage and Alfred Stieglitz. University of California Press, Berkeley, CA.

Peterson, C. A. 1997. After the Photo-Secession: American Pictorial Photography 1910-1955. The Minneapolis Institute of Arts in Association with W.W. Norton \& Company, New York and London.

Reichert Powell, D. 2007. Critical Regionalism: Connecting Politics and Culture in the American Landscape. The University of North Carolina Press, Chapel Hill, NC.

Riley, G. 2000. Writing, teaching, and recreating western history through intersections and viewpoints. Pages 103-121 In: The American West: Interactions, Intersections, and Injunctions. F. M. Bakken and B. Farrington (eds.). Garland, New York.

Sailor, R. 2014. Meaningful Places: Landscape Photographers in the Nineteenth Century American West. University of New Mexico Press, Albuquerque, NM.

Slotkin, R. 2002. Visual narrative and American myth from Thomas Cole to John Ford. Pages 91112 In: American Victorians and Virgin Nature. T. J. Jackson Lears (ed.). Isabella Stewart Gardner Museum, Boston, MA. 